\title{
Sistem Informasi Geografis Perumahan Di Kota Manado Berbasis Web
}

\author{
Jenry Jimmy Masudara ${ }^{1)}$, Yaulie D. Y. Rindengan ${ }^{2)}$, Xaverius B. N. Najoan ${ }^{3)}$ \\ Program Studi Teknik Informatika, Fakultas Teknik, Universitas Sam Ratulangi \\ E-mail : .jenrymasudara7317@ gmail.com ${ }^{1)}$,rindengan@unsrat.ac.id ${ }^{2)}$,xnajoan@ unsrat.ac.id ${ }^{3)}$
}

\begin{abstract}
Abstrak - Kota Manado sebagai salah satu kota dengan keadaan penduduk yang makin padat dan kebutuhan masyarakat yang ingin mencari informasi tentang perumahan dengan cepat, membuat Sistem Informasi Geografis sangat diperlukan, terutama dalam hal pencarian lokasi perumahan. Oleh karena itu, penulis membuat sistem informasi geografis perumahan di kota Manado berbasis web dengan menggunakan HTML(HyperText Markup Language), PHP(Perl HyperText Preprocessor), CSS(Cascading Style Sheets) dan JavaScript untuk merancang antarmuka dan logika sistem, MySQL untuk perancanagan database sistem dan google API untuk pemetaan. Informasi yang disajikan berupa nama perumahan, alamat, foto perumahan, gambar tipe rumah, denah rumah, ketersediaan dan harga dari tiap tipe rumah. Dengan adanya SIG(Sistem Informasi Geografis) ini diharapkan masyarakat dapat lebih mudah dan cepat mendapatkan informasi perumahan di kota Manado.
\end{abstract}

Kata Kunci : Berbasis Web, Google API, Perumahan, SIG

\section{PENDAHULUAN}

Sejak dahulu rumah telah menjadi prioritas utama bagi manusia sebagai kebutuhan primer untuk memenuhi kelangsungan hidup yang nyaman bagi manusia itu sendiri. Dewasa ini seiring dengan berkembangnya pembangunan di setiap daerah, terutama daerah yang letaknya strategis dengan pusat-pusat pembangunan seperti ibukota, selayaknyalah banyak para perusahaan properti besar membangun kawasan perumahan khususnya di wilayah kota Manado. Sehingga makin banyaknya jumlah perumahan yang tersebar di wilayah kota Manado.

Kebutuhan akan mendapatkan suatu informasi secara cepat dan tepat, telah menjadi kebutuhan pokok masyarakat. Internet menjadi saran untuk mendapatkan dan menyebarkan informasi dengan cepat. Internet merupakan media informasi berbasis jaringan yang dapat diakses dimana saja dengan biaya yang relatif murah. Dengan adanya internet, kita juga akan lebih mudah untuk melihat kondisi atau keberadaan suatu tempat.

Salah satu kebutuhan informasi adalah informasi geografis. Teknologi Sistem Informasi Geografis merupakan suatu teknologi mengenai geografis yang memiliki kemampuan dalam memvisualisasikan data spasial berikut atributatributnya. Manado sebagai salah satu kota dengan keadaan geografis yang mulai padat dan kebutuhan masyarakat yang ingin mencari informasi tentang perumahan dengan cepat, membuat Sistem Informasi Geografis sangat diperlukan, terutama dalam hal pencarian lokasi perumahan. Dengan adanya latar belakang diatas, maka dibuatlah Sistem Informasi Geografis Perumahan Berbasis Web, dengan tujuan untuk memberikan informasi mengenai lokasi atau letak perumahan dan informasi tentang perpumahan tersebut.

\section{LANDASAN TEORI}

\section{A. Sistem Informasi Geografis}

Sistem Informasi Geografis (Geographic Information System / GIS) adalah sistem informasi khusus yang mengelola data yang memiliki informasi spasial (bereferensi keruangan). Atau dalam arti yang lebih sempit, adalah sistem komputer yang memiliki kemampuan untuk membangun, menyimpan, mengelola dan menampilkan informasi berefrensi geografis, misalnya data yang diidentifikasi menurut lokasinya, dalam sebuah database.

Secara umum pengertian Sistem Informasi Geografis adalah Suatu komponen yang terdiri dari perangkat keras, perangkat lunak, data geografis dan sumberdaya manusia yang bekerja bersama secara efektif untuk memasukan, menyimpan, memperbaiki, memperbaharui, mengelola, memanipulasi, mengintegrasikan, menganalisa dan menampilkan data dalam suatu informasi berbasis geografis. ( Prahasta, Eddy. 2003 )

\section{B. Metode Waterfall}

Menurut Pressman (2010), model waterfall adalah model klasik yang bersifat sistematis, berurutan dalam membangun software. Nama model ini sebenarnya adalah "Linear Sequential Model". Model ini sering disebut dengan "classic life cycle" atau model waterfall. 


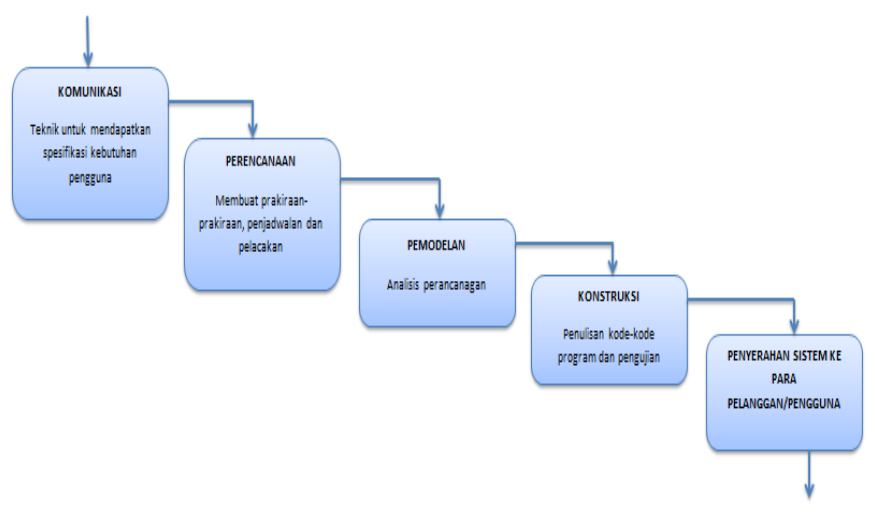

Gambar 1. Tahapan Pengembangan dengan metodologi waterfall (Roger S. Pressman)

Berikut adalah penjelasan dari tahap-tahap yang dilakukan dalam model Waterfall :

\section{Komunikasi}

Langkah ini merupakan analisa terhadap kebutuhan sistem. Pengumpulan data dalam tahap ini bisa malakukan sebuah penelitian, wawancara atau study literatur.

2. Perencanaan

Tahapan ini akan menghasilkan jadwal atau rencana yang akan dilakukan dalam penelitian.

\section{Pemodelan}

Proses desain akan menerjemahkan syarat kebutuhan ke sebuah perancangan perangkat lunak yang dapat diperkirakan sebelum dibuat coding.

4. Konstruksi

Konstruksi merupakan tahapan pembuatan kode atau Coding. Coding merupakan penerjemahan design atau pemodelan dalam bahasa yang bisa dikenali oleh komputer. Setelah pengkodean selesai maka akan dilakukan testing terhadap sistem yang telah dibuat. Tujuan testing adalah menemukan kesalahan-kesalahan terhadap sistem tersebut dan kemudian bisa diperbaiki.

5. Penyerahan sistem ke para pelanggan/pengguna

Tahapan ini bisa dikatakan final dalam pembuatan sebuah sistem. Setelah melakukan analisa, design dan pengkodean maka sistem yang sudah jadi akan digunakan oleh user.

\section{METODOLOGI PENELITIAN}

Sesuai dengan gambar 1 metodologi penelitian ini menggunakan metode waterfall sehingga tahap penelitian yang dilakukan adalah sebagai berikut:

\section{A. Komunikasi}

Tahap ini penulis melakukan observasi langsung ke perumahan-perumahan yang ada di kota manado untuk mendapatkan data berupa informasi tentang perumahan tersebut. Data yang diperoleh berupa brosur yang berisi nama perumahan, alamat perumahan, tipe-tipe rumah yang dijual dan harga.

Pengambilan data ini dilakukan untuk mendapatkan informasi yang akan di masukan dalam sistem informasi geografis yang akan di bangun.

1. Analisis Kebutuhan

Analisis kebutuhan digunakan untuk mengidentifikasi kebutuhan sistem yang akan dibangun. Kebutuhan sistem meliputi kebutuhan user dan kebutuhan admin. Sistem akan menampilkan informasi kepada user dengan memproses data yang telah tersimpan dalam basis data.

a. Kebutuhan User

Kebutuhan user meliputi apa saja yang dibutuhkan oleh user pada sistem informasi geografis perumahan berbasis web ini berupa :

○ Tampilan tentang pemetaan perumahan di kota Manado.

- Informasi tentang perumahan-perumahan yang ada di kota Manado.

\section{b. Kebutuhan admin}

Kebutuhan admin pada sistem ini meliputi apa saja yang dibutuhkan admin pada sistem ini berupa :

○ Mengolah data informasi tentang perumahan.

- Melakukan proses marker perumahan di kota Manado.

- Melakukan penambahan atau pengeditan perumahan.

2. Analisis Proses Bisnis

Menggambarkan proses bisnis kegiatan para pengguna sistem pada umumnya dapat dilihat melalui diagram aktivitas seperti gambar 2 :

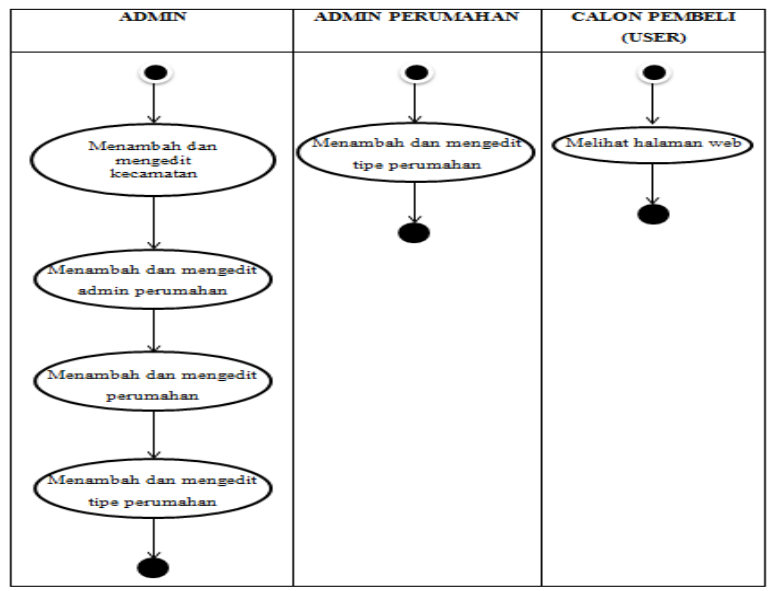

Gambar 2. Analisis Proses Bisnis 


\section{B. Perencanaan}

Tahap ini penulis menyusun rencana kerja yang akan dilakuakan untuk membangun perangkat lunak yaitu dalam hal ini adalah Sistem Informasi Geografis Perumahan di Kota Manado Berbasis Web.

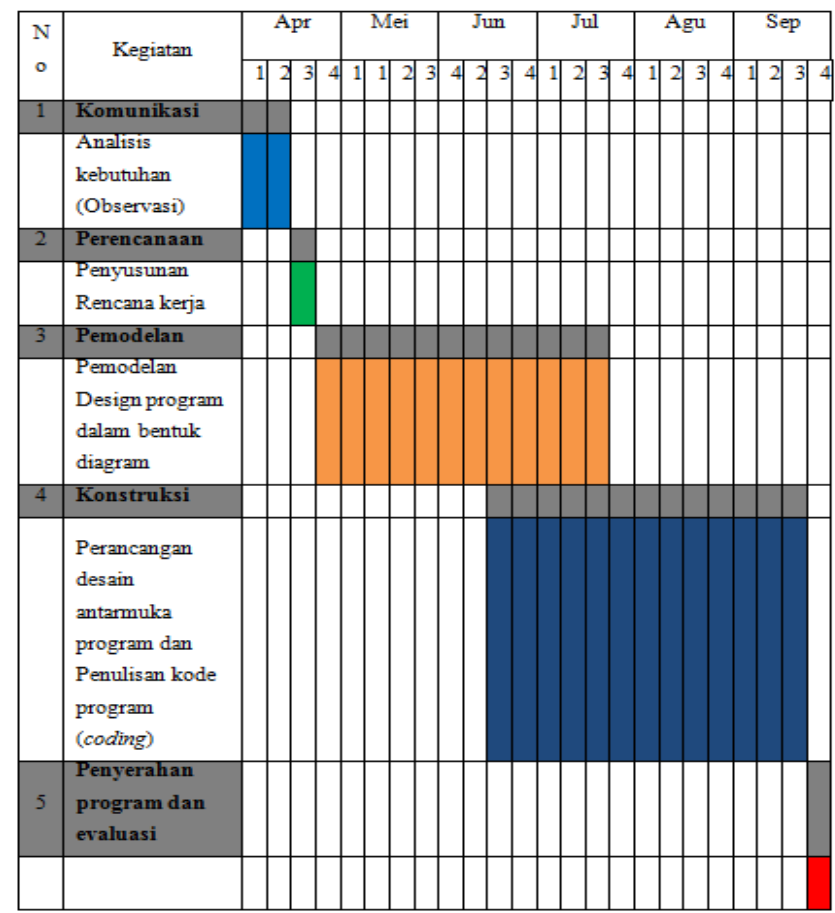

Gambar 3. Rencana Kerja

\section{Pemodelan}

Tahap ini semua hasil analisa kebutuhan pengguna dan kebutuhan sistem informasi geografis didefinisikan dalam bentuk diagram UML sedangkan interface sistem dimodelkan dengan storyboard.

\section{Use Case Diagram}

Use case diagram dirancang untuk menunjukkan secara umum fungsi dan tanggung jawab masingmasing aktor dalam Sistem Informasi Geografis yang dibangun. Use case diagram dari Sistem Informasi Geografis dapat dilihat pada gambar 4.

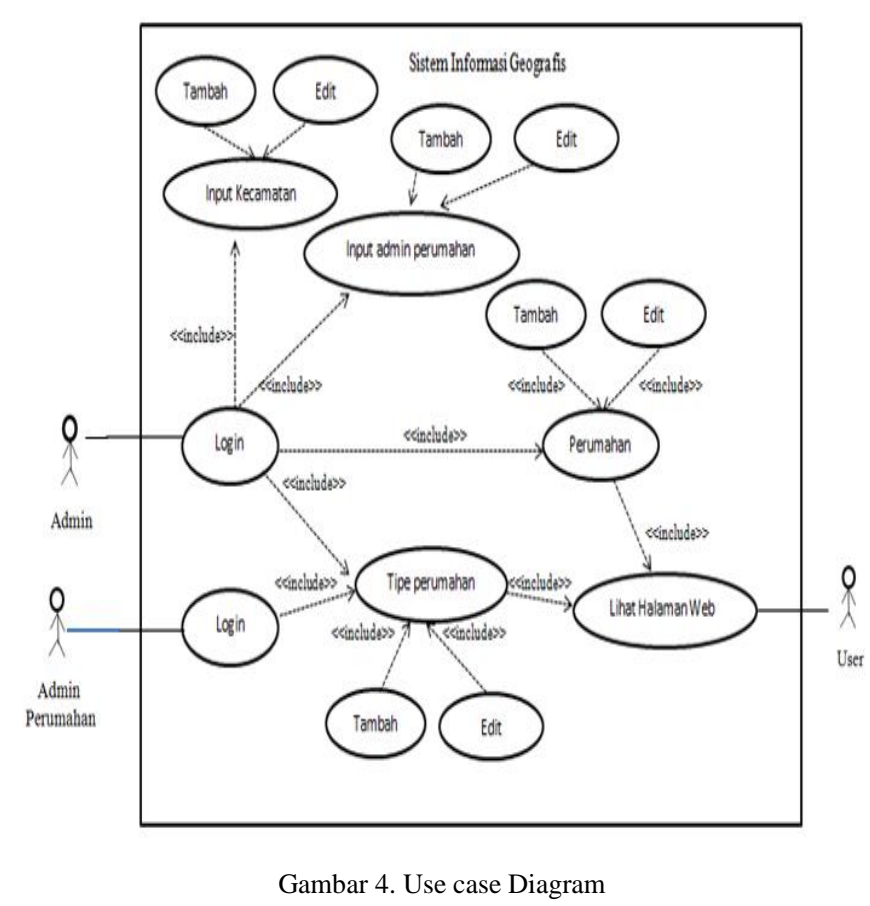

2. Activity Diagram

Merupakan gambaran tentang aktivitas-aktivitas berurutan yang akan dilakukan pengguna pada sistem informasi geografis perumahan. Activity diagram dapat dilihat pada gambar 5 .

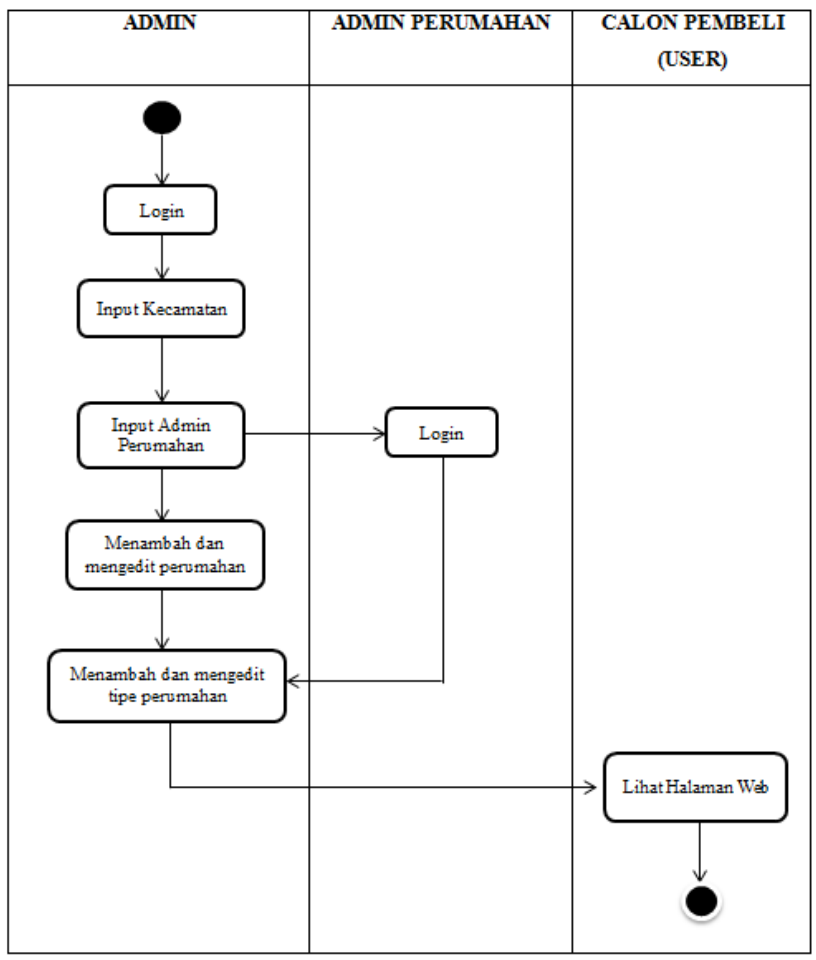

Gambar 5. Activity Diagram

Gambar Activity diagram menjelaskan proses alur bagaimana user dapat melihat website dari sistem informasi geografis. 
a. Admin menginput data admin perumahan tiap perumahan dan kecamatan.

b. Admin dapat menambah atau mengubah data perumahan dan tipe perurumahan.

c. Admin perumahan hanya dapat menambah atau mengubah data tipe perumahan.

d. Setelah semua data sudah di isi dalam sistem, user dapat melihat informasi dalam website.

3. Tabel Relasi

Menunjukkan relasi antar tabel beserta namanama atributnya yang digunakan pada sistem informasi yang di bangun. Gambar tabel relasi dapat di lihat pada gambar 6.
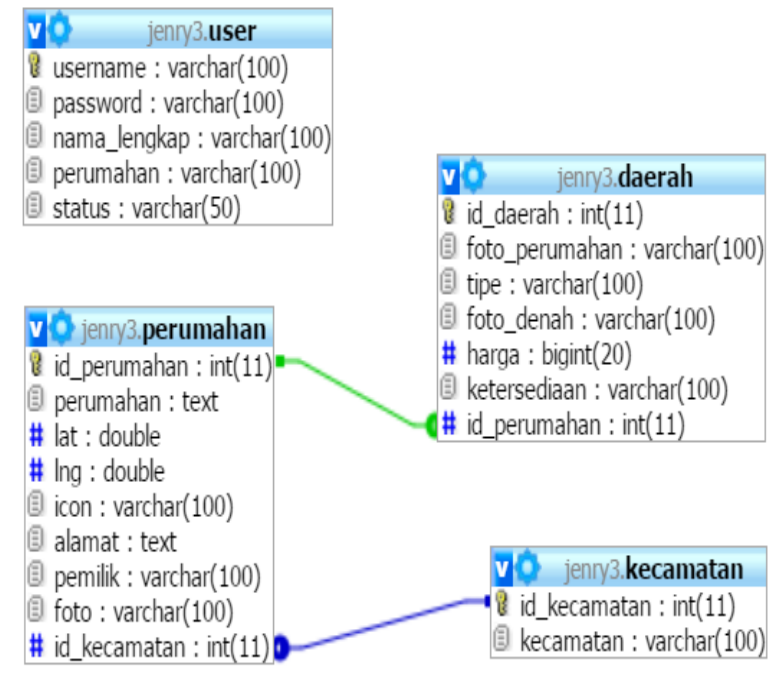

Gambar 6. Tabel Relasi

\section{Storyboard}

Untuk merancang interface sistem informasi perumahan, penulis menggunakan storyboard untuk menggambarkan tampilan dari sistem yang akan dibuat.

\section{a. Halaman utama}

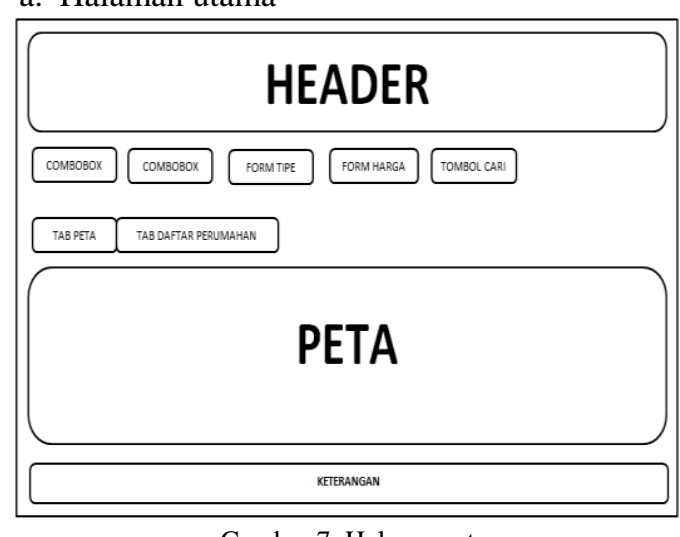

Gambar 7. Halaman utama

1. Combobox berisi daftar semua perumahan yang ada di dalam sistem informasi geografis.

2. Combobox berisi daftar kecamatan yang ada di kota Manado.

3. Terdapat 2 form untuk melakukan fungsi pencarian. Form tipe dapat di isi dengan menuliskan pencarian menurut tipe perumahan dan form harga untuk pencarian menurut harga.

4. Tombol cari berfungsi untuk mengseksekusi form tipe, form harga dan combobox.

5. Peta yaitu berisi maps lokasi-lokasi perumahan yang ada di kota Manado.

6. Keterangan berisi petunjuk nama kecamatan.

b. Halaman model perumahan

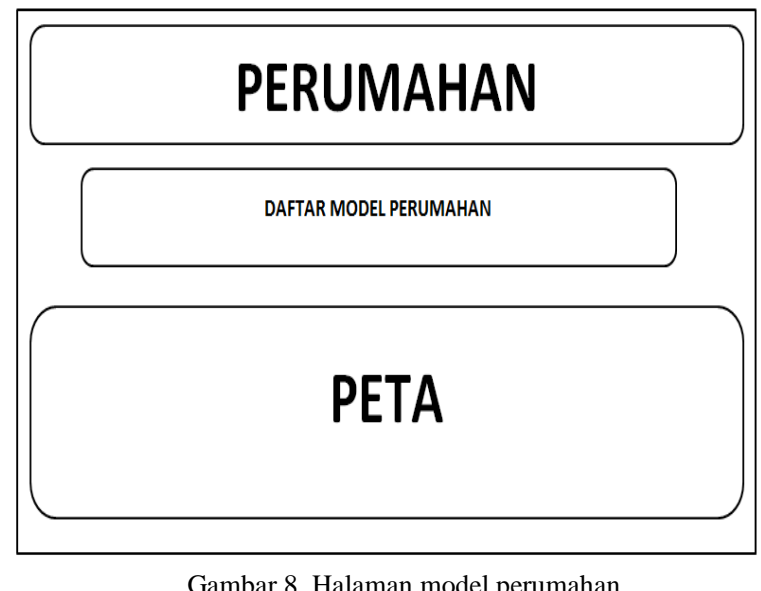

1. Perumahan merupakan text area yang berisi nama perumahan, alamat perumahan, kecamatan dan pemilik perumahan.

2. Daftar model perumahan berisi tentang informasi tipe-tipe rumah yang di jual berupa gambar rumah, denah, ketersediaan dan harga.

3. Peta berisi maps lokasi perumahan.

\section{c. Halaman Admin}

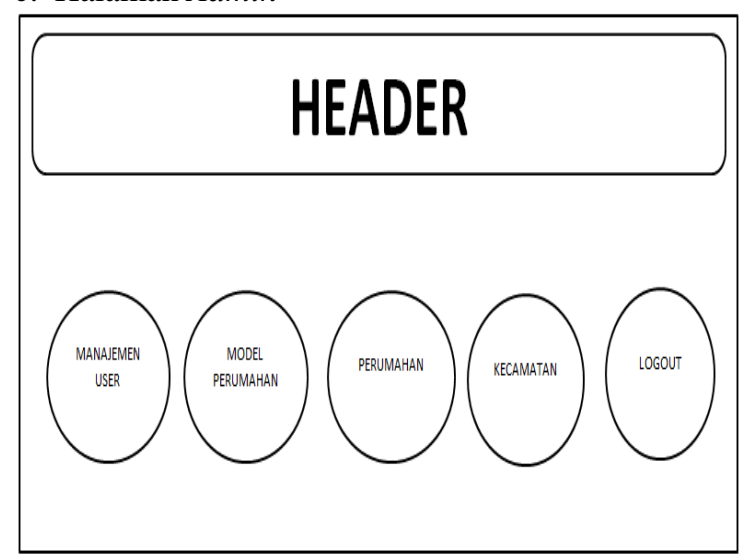

Gambar 9. Halaman admin 
1. Tombol management user berisi link untuk mengakses halaman pengaturan user dalam hal ini admin tiap perumahan.

2. Tombol model perumahan berisi link untuk mengakses halaman menambah atau mengedit perumahan yang ada di kota Manado.

3. Tombol model perumahan berisi link untuk mengakses halaman menambah atau mengedit tipe perumahan.

4. Tombol Kecamatan berisi link untuk mengakses halaman menambah dan mengedit kecamatan.

\section{Konstruksi}

Tahap konstruksi bertujuan untuk membangun sistem berdasarkan hasil desain modeling yang telah dilakukan sebelumya dengan cara coding atau kodifikasi program. Kodifikasi program adalah proses penulisan source code atau kode-kode sumber. Source code yang digunakan dalam membangun sistem dalam penelitian ini antara lain source code HTML, CSS dan JavaScript sebagai perancanagan antarmuka sistem, source code PHP sebagai bahasa pemrograman yang membentuk logika atau proses dari sistem, Google API untuk membuat tampilan peta berada pada halaman web dan MySQL untuk database sistem.

\section{HASIL DAN PEMBAHASAN}

\section{A. Halaman Utama}

Halaman utama berisi informasi pemetaan perumahan di kota Manado dan daftar perumahan yang ada di kota manado. Juga terdapat fitur pencarian menurut tipe rumah, harga rumah dan daerah atau kecamatan. Halaman utama dapat dilihat pada gambar 10.

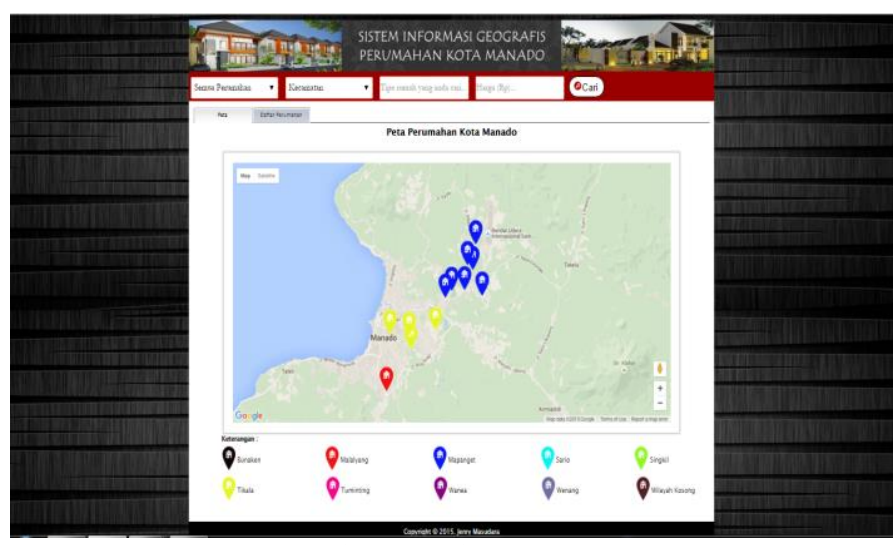

Gambar 10. Halaman Utama

\section{B. Halaman Utama Daftar Perumahan}

Halaman utama daftar perumahan ini berisi informasi daftar perumahan beserta tipe perumahan yang ada di kota Manado. Dapat dilihat pada gambar 11.

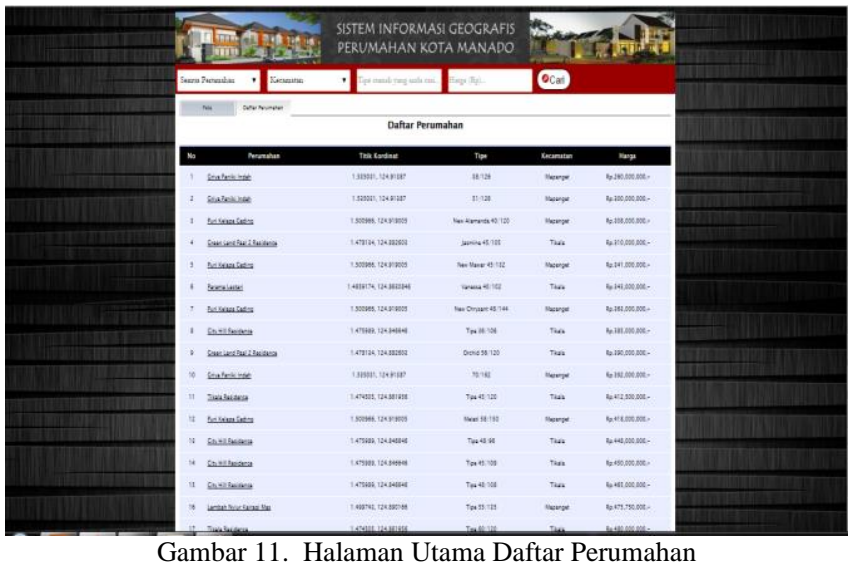

\section{Halaman Utama Perumahan}

Halaman utama perumahan ini berisi tentang informasi pada setiap perumahan yang ada di kota Manado. Informasi berupa nama tipe perumahan, gambar rumah, denah rumah dan harga. Dapat dilihat pada gambar 12.

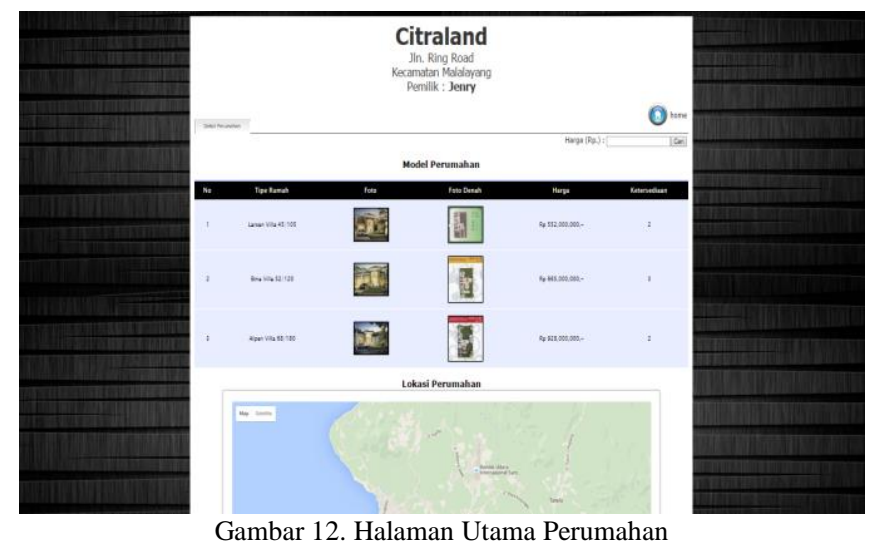

\section{Halaman Utama Admin}

Halaman utama admin berisi tentang pengaturan seluruh sistem yaitu pengaturan tambah dan edit perumahan, tambah dan edit tipe perumahan, menambah user atau admin di masing-masing perumahan dan menambah dan mengedit kecamatan. Dapat dilihat pada gambar 13.

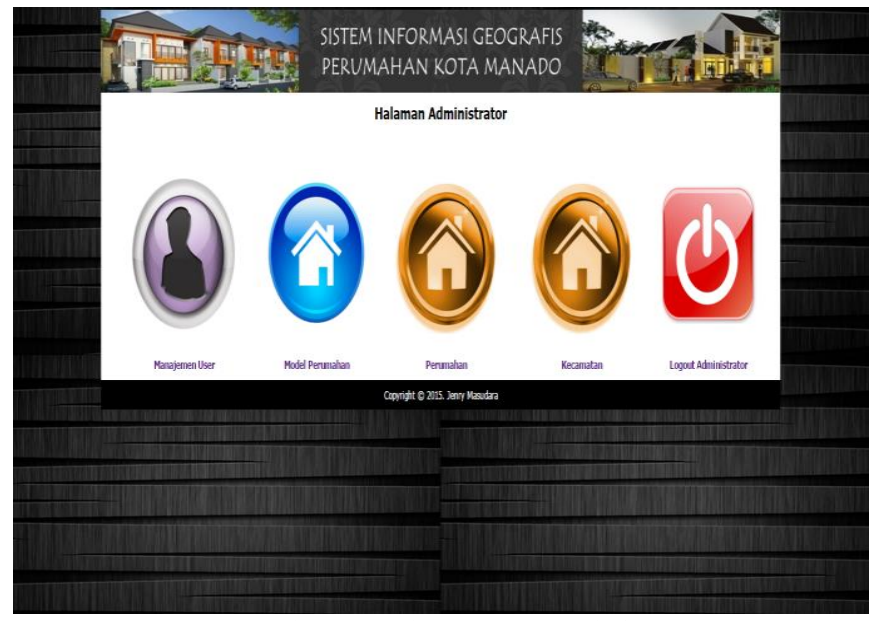

Gambar 13. Halaman Utama Admin 


\section{E. Pembahasan}

Berdasarkan hasil dan ujicoba yang telah dilakukan, sistem informasi geografi perumahan di kota Manado berbasis web telah berfungsi sesuai tujuan yang yang telah ditetapkan sebelumnya. Adapun fungsi-fungsi dari sistem yang telah dibuat sebagai berikut :

1. Halaman utama sistem berisi informasi letak perumahan yang di tunjukan lewat peta dan daftar perumahan di kota manado.

2. Informasi yang di tunjukan berupa nama perumahan, tipe rumah yang di jual, harga, ketersediaan, foto, denah rumah dan harga.

3. Terdapat 2 admin yang mengatur sistem ini yakni, super admin yang mengatur semua sistem yang ada mulai dari memanbah perumahan, menambah tipe perumahan, menambah admin perumahan dan mengedit semuanya itu. Dan admin perumhan yang hanya dapat menambah dan mengedit tipe perumhan saja.

\section{PENUTUP}

\section{A. Kesimpulan}

Dari hasil penelitian ini, telah dihasilkan suatu Sistem Informasi Geografis Perumahan di Kota Manado berbasis web yang dapat digunakan sebagai sarana penyampaian informasi tentang perumahan yang ada di kota Manado.

Dengan adanya sistem informasi geografis ini kiranya dapat membantu masyarakat untuk mencari informasi perumahan lebih cepat dan mendapatkan informasi alamat atau geografis perumahan di Kota Manado.

\section{B. Saran}

Penulis menyadari bahwa Sistem Informasi Geografis yang dibuat masih banyak kekurangan dan penulis mengharapkan agar ke depannya nanti Sistem Informasi Geografis yang akan dibuat bisa lebih dikembangkan lagi seperti, membuat Sistem Informasi Geografis berbasis Android atau mengembangkan pemetaannya menggunakan tools yang lain.

\section{DAFTAR PUSTAKA}

[1] Hartono, Jogiyanto, 1999. Analisis dan Design Sistem Informasi: pendekatan terstruktur teori dan praktek aplikasi bisnis, Andi. Yogyakarta

[2] Janner, Simarmata, 2009. Rekayasa WEB, Andi. Yogyakarta.

[3] Prahasta, Eddy. 2009. Sistem Informasi Geografis Konsep - konsep Dasar, Penerbit Informatika.Bandung. Bandung.

[4] Roger, S. Pressman, 2010. Rekayasa Perangkat Lunak Edisi 7, Andi. Yogyakarta.

[5] Wayan. 2011. Sistem Informasi geografis berbasis web untuk pemetaan wisata kabupaten Gianyar, Universitas Pembangunan Nasional "Veteran", Yogyakarta.

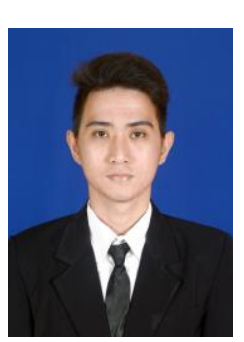

Penulis bernama lengkap Jenry Jimmy Masudara, anak pertama dari dua bersaudara. Lahir di Manado, Sulawesi Utara, pada tanggal 15 Juni 1992. Dengan alamat tempat tinggal sekarang di Kecamatan Wanea, Kelurahan Wanea lingkungan 4 No.121. Sekolah pertama tempat belajar adalah Taman Kanak-Kanak Tabita Manado. Selanjutnya, melanjutkan ke SD Negeri 4 Manado. Selanjutnya, melanjutkan ke SMP Negeri 1 Manado. Dan menyelesaikan sekolah tingkat atas di SMA Negeri 1 Manado. Pada tahun 2010, Penulis melanjutkan studi di Fakultas Teknik, Jurusan Elektro, Program Studi Informatika Universitas Sam Ratulangi Manado. Selama kuliah, Penulis pernah melakukan kerja praktek di PT. Telekomunikasi Indonesia cabang Manado. Dan tergabung dalam organisasi Himpunan Mahasiswa Elektro (HME).

. Kemudian pada tahun 2014 bulan desember penulis membuat skripsi demi memenuhi syarat Sarjana (S1) dengan penelitian berjudul "Sistem Informasi Geografis Perumahan Di Kota Manado Berbasis Web" yang di bimbing oleh Yaulie D. Y. Rindengan, ST., MSc., MM sebagai dosen pembimbing I dan Xaverius B. N. Najoan, ST., MTI sebagai dosen pembimbing II, sehingga pada tanggal 23 Oktober 2015 penulis resmi lulus di Teknik Informatika Universitas Sam Ratulangi dan menyandang gelar sebagai Sarjana Komputer dengan Predikat Sangat Memuaskan. 